\title{
Reactivity of a Trimethylstannyl Molybdenum Complex in Mesoporous MCM-41
}

\author{
Christian Huber, Karin Moller and Thomas Bein* \\ Department of Chemistry, Purdue University, West Lafayette, IN 47907, USA
}

A highly thermostable tin-molybdenum complex is encapsulated into the hexagonal mesoporous channel host MCM-41 and thermally transformed into supported metal clusters.

The recent discovery of a new class of ordered mesoporous materials $^{1}$ with channel diameters between about 20 and 100 $\AA$ has opened up new opportunities for the design of hybrid catalysts. The immobilization of transition-metal catalysts on solid supports has been the focus of many research efforts. ${ }^{2-6}$ Key challenges in the design of these catalysts include (i) control over the species that is actually immobilized, and (ii) sufficient stability against deactivation and leaching. The novel mesoporous MCM-41 hosts are prepared in liquid crystalline phases where combinations of amphiphile-metaloxo systems order in channel or layer structures. In the case of aluminosilicate MCM-41, the pore system obtained after calcination presents well-defined hexagonal walls with terminal hydroxyl groups at $3745 \mathrm{~cm}^{-1}$ (in vacuum). Surface reactions with organometallic compounds should therefore produce well-defined species, in contrast to the situation on some amorphous supports. The enormous pore sizes of the MCM-41 family offer new opportunities for the encapsulation of large catalyst species and for the catalytic conversion of substrates much larger than in common zeolites.

We have recently developed a concept for stabilizing low-valent transition-metal moieties [such as $\mathrm{Cl}_{2}$ (THF)Ge$\mathrm{Mo}(\mathrm{CO})_{5}{ }^{7}$ or $\left.\mathrm{Me}_{3} \mathrm{SnMn}(\mathrm{CO})_{5}\right]^{8}$ in large-pore zeolites, by using bimetallic complexes where the second, oxophilic main-group element serves to attach the complex to the internal zeolite cage surface. This communication describes the attachment of the bimetallic complex $\mathrm{Me}_{3} \mathrm{SnMo}(\mathrm{CO})_{3}(\eta-$ $\mathrm{C}_{5} \mathrm{H}_{5}$ ) into the hexagonal channels of MCM-41. This system also provides a convenient precursor for highly dispersed SnMo clusters made by thermolysis of the encapsulated complex.

All manipulations were carried out under nitrogen atmosphere, in thoroughly dried solvents, or high vacuum. The precursor $\mathrm{Me}_{3} \mathrm{SnMo}(\mathrm{CO})_{3}\left(\eta-\mathrm{C}_{5} \mathrm{H}_{5}\right) \quad\left(\mathrm{mp} 97-99^{\circ} \mathrm{C}\right)$ was synthesized from the reaction between $\mathrm{Na}\left[\mathrm{Mo}(\mathrm{CO})_{3}(\eta-\right.$ $\left.\mathrm{C}_{5} \mathrm{H}_{5}\right)$ ] and $\mathrm{Me}_{3} \mathrm{SnCl}$ following a modified reported method. ${ }^{9}$ The hexagonal channel host MCM-41 (unit cell size, $4.0 \mathrm{~nm}$; channel diameter, $c a$. $3.0 \mathrm{~nm}$ ) was synthesized using $\mathrm{C}_{16} \mathrm{H}_{33} \mathrm{NMe}_{3} \mathrm{OH}$ according to published procedures. ${ }^{1} \mathrm{MCM}$ 41 was degassed by calcination in oxygen for $4 \mathrm{~h}$ at $100^{\circ} \mathrm{C}$ and

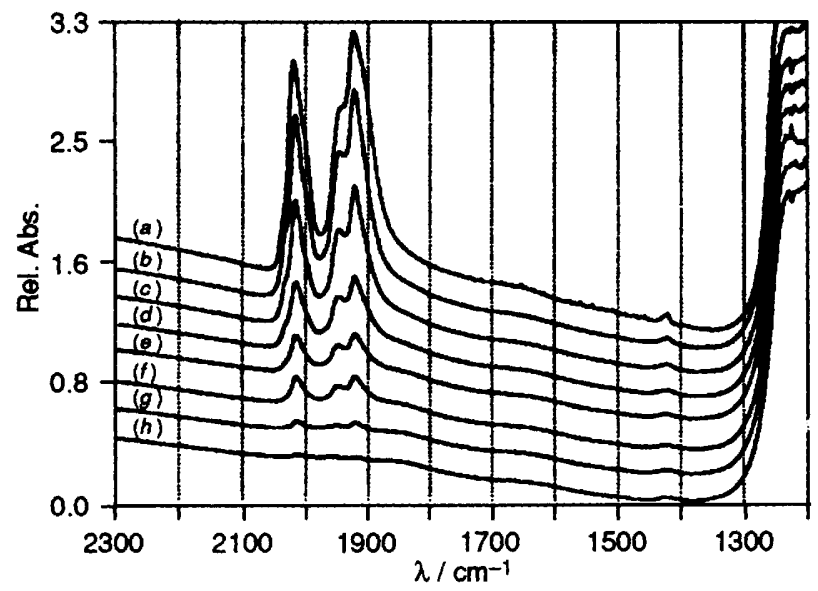

Fig. I In situ FTIR spectra of $\mathrm{Me}_{3} \mathrm{SnMo}(\mathrm{CO})_{3}\left(\eta-\mathrm{C}_{5} \mathrm{H}_{5}\right)$ in the MCM-41 host under vacuum: (a) 30, (b) 290, (c) 320, (d) 340, (e) 360, (f) $370,(g) 390,(h) 400^{\circ} \mathrm{C}$. Heating rate $2^{\circ} \mathrm{C} \mathrm{min}^{-1}$ Peaks observed at $2019,1948,1921$ and $1422 \mathrm{~cm}^{-1}$. for $8 \mathrm{~h}$ at $540^{\circ} \mathrm{C}$, followed by evacuation at $400^{\circ} \mathrm{C}$ for $6 \mathrm{~h}\left(10^{-5}\right.$ Torr; heating rate $\left.1^{\circ} \mathrm{C} \mathrm{min}-1\right)$. The host was loaded with 1.5 mmol of $\mathrm{Me}_{3} \mathrm{SnMo}(\mathrm{CO})_{3}\left(\eta-\mathrm{C}_{5} \mathrm{H}_{5}\right)$ per $\mathrm{g}$ of host in $50 \mathrm{ml}$ of dry hexane by stirring the slurry for $18 \mathrm{~h}$, followed by washing and drying under vacuum. For thermal stability studies, $0.5 \mathrm{~g}$ batches of loaded host where heated in a tube furnace under $10^{-5}$ Torr at the desired temperatures (heating rate $1{ }^{\circ} \mathrm{C}$ $\min ^{-1}$, isothermal for $6 \mathrm{~h}$ ). EXAFS measurements at the Mo K-edge $(20000 \mathrm{eV})$ and the Sn K-edge $(29200 \mathrm{eV})$ were carried out at NSLS (Brookhaven National Laboratories) at beamline X-11A with a stored energy of $2.5 \mathrm{GeV}$ and ring currents between $100-200 \mathrm{~mA}$, at about $100 \mathrm{~K}$ in transmission using a double-crystal $\mathrm{Si}(311)$ monochromator.

If the carbonyl stretching region of the precursor (in hexane: 2001,1927 , and $1904 \mathrm{~cm}^{-1}$ ) is compared with that of

(a)

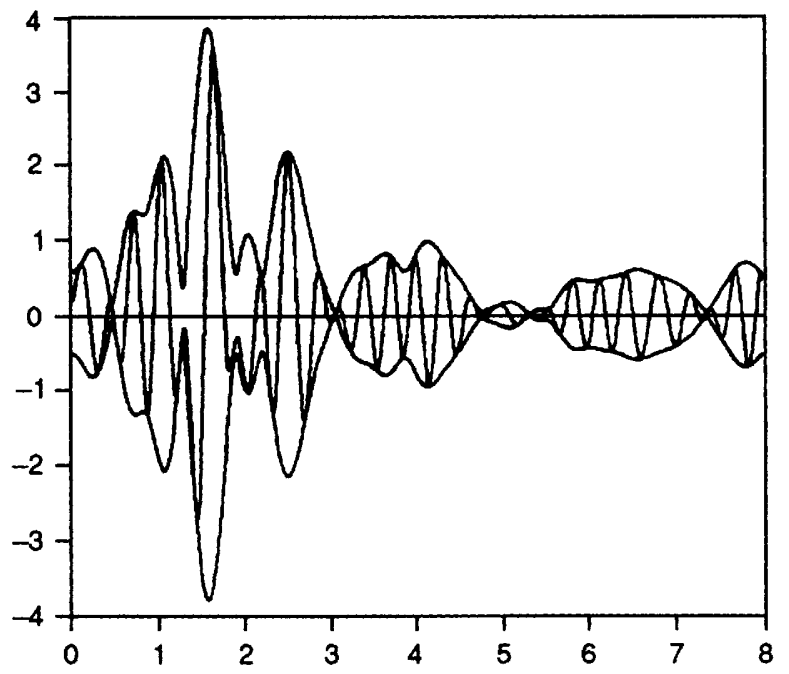

(b)

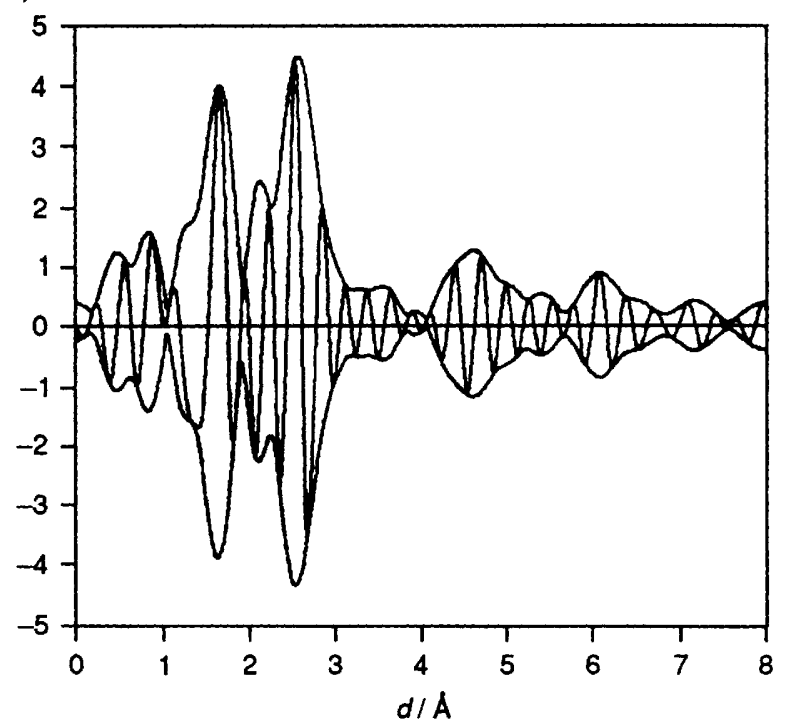

Fig. 2 Fourier-transformed EXAFS data of $\mathrm{Me}_{3} \mathrm{SnMo}(\mathrm{CO})_{3}\left(\eta-\mathrm{C}_{5} \mathrm{H}_{5}\right)$ in MCM-41 at different treatment temperatures: (a) Sn-edge, $30^{\circ} \mathrm{C}$; (b) Sn-edge, $300^{\circ} \mathrm{C}$ 


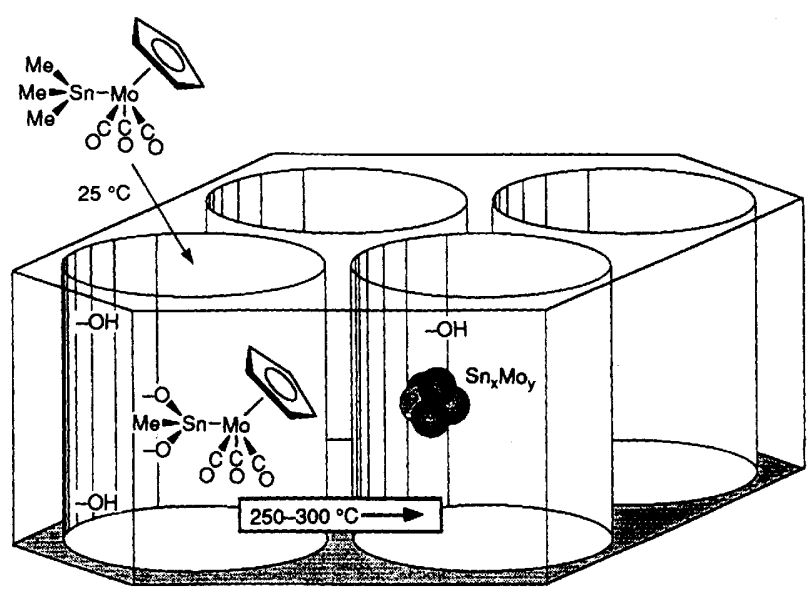

Fig. 3 Proposed intrazeolite chemistry of $\mathrm{Me}_{3} \mathrm{SnMo}(\mathrm{CO})_{3}\left(\eta-\mathrm{C}_{5} \mathrm{H}_{5}\right)$ in the MCM-41 host (schematic)

the complex in MCM-41 $\left(2019,1948\right.$, and $\left.1921 \mathrm{~cm}^{-1}\right)$ only moderate changes are observed (in situ FTIR spectroscopy; Fig. 1). This shows that there are no significant surface-CO interactions present such as those observed with carbonyl complexes in Na-containing zeolites (e.g. ref. 8). The hydroxyl region (monitored in the first overtone) shows a significant reduction of the intensity of the band at $7328 \mathrm{~cm}^{-1}$, supporting the idea that the trimethyl tin moiety reacts with the surface.

In situ FTIR-TPD experiments with the SnMo complex in MCM-41 show the striking stability of the above-mentioned triplet of CO stretching bands when heating up to about $290^{\circ} \mathrm{C}$ (Fig. 1). Only above $320^{\circ} \mathrm{C}$ is a slow decrease in intensity visible, and the subsequent destruction of the $\mathrm{CO}$ species between 320 and $400{ }^{\circ} \mathrm{C}$ occurs without any significant change in band position, relative intensities, and without formation of intermediates. A slight increase of $\mathrm{CO}$ evolution becomes visible above about $200^{\circ} \mathrm{C}$, with a maximum as high as $350^{\circ} \mathrm{C}$ (TPD-MS spectra). Methane evolution with a maximum at $360^{\circ} \mathrm{C}$ is also observed.

EXAFS data show the following: The bimetallic complex remains intact at the Mo moiety when adsorbed into the dry $\mathrm{MCM}$ host (Mo-CO, 3.4 ligands at $3.15 \AA$ ). The Mo-edge shape is similar to that of the precursor. The tin coordination sphere is consistent with three $\mathrm{C} / \mathrm{O}$ groups $\left[\mathrm{Sn}-\mathrm{C} / \mathrm{O}_{3.2}\right.$ at 2.08 A; Fig. 2(a)]. This distance is significantly shorter than that of the precursor $(2.15 \AA)$, indicating surface attachment with oxygen substitution at tin. This is confirmed by the Sn-edge shape that shows loss of $\mathrm{Sn}-\mathrm{C}$ features. The second tin shell is assigned to $\mathrm{Sn-Mo}$ backscattering (reliable fits are difficult because of overlapping shells).

At $300{ }^{\circ} \mathrm{C}, \dagger$ the Sn-edge EXAFS shows coordination to oxygen $(3.5 \mathrm{O}$ at $2.08 \AA$ ), and a significant increase of the second-shell amplitude, due to metal backscattering [Fig. $2(b)]$. These changes can be compared with a remarkable increase of absorption in the near IR spectra, and indicate the formation of metallic molybdenum-tin clusters in the MCM host after thermal decomposition of the precursor complex.

In summary, the reaction of $\mathrm{Me}_{3} \mathrm{SnMo}(\mathrm{CO})_{3}\left(\eta-\mathrm{C}_{5} \mathrm{H}_{5}\right)$ with the walls of hexagonal mesoporous MCM-41 leads to intra- channel attachment of the bimetallic species via removal of some of the methyl ligands already at room temp. The attached complex is extremely stable and starts to dissociate $\mathrm{CO}$ only above $\mathrm{ca} .200^{\circ} \mathrm{C}$, and converts into sub-nanometer size Sn-Mo metal clusters at about $300^{\circ} \mathrm{C}$, as depicted in Fig. 3 . Initial catalytic studies of this system show high activity of the intact, attached bimetallic complex for olefin hydrogenation.

The striking thermal stability of these encapsulated organometallic and metal cluster species permits further studies of their chemical reactivity and catalytic activity.

The authors thank Professor D. C. Koningsberger for software for EXAFS data analysis. Funding from the US Department of Energy for this work is gratefully acknowledged. The operational funds for NSLS beamline X-11A are supported by DOE grant DE-AS0580ER10742.

Received, 4th July 1994; Com. 4/04054F

\section{Footnote}

$\dagger$ These temperatures can not be directly compared with the in situ IR measurements because batch processes take much longer than desorption from thin films.

\section{References}

1 J. S. Beck, J. C. Vartuli, W. J. Roth, M. E. Leonowicz, C. T. Kresge, K. D. Schmitt, C. T.-W. Chu, D. H. Olson, E. W. Sheppard, S. B. McCullenil, J. B. Higgins and J. L. Schlenker, J. Am. Chem. Soc., 1992, 114, 10834; C. T. Kresge, M. E. Leonowicz, W. Roth, J. C. Vartuli and J. S. Beck, Nature, 1992, 359, 710; A. Monnier, F. Schüth, Q. Huo, D. Kumar, D. Margolese, R. S. Maxwell, G. D. Stucky, M. Krishnamurty, P. Petroff, A. Firouzi, M. Janicke and B. F. Chmelka, Science, 1993, 261, 1299; Q. Huo, D. I. Margolese, U. Ciesla, P. Feng, T. E. Gier, P. Sieger, R. Leon, P. M. Petroff, F. Schüth and G. D. Stucky, Nature, 1994, 368, 317.

2 B. C. Gates, L. Guczi and H. Knözinger, Metal Clusters in Catalysis, Elsevier: Amsterdam, 1986; Surface Organometallic Chemistry; Molecular Approaches to Surface Catalysis, ed. J.-M. Basset, B. C. Gates, J. P. Candy, A. Choplin, M. Leconte, F. Quignard and C. Santini, Kluwer, Dordrecht, 1988; J.-M. Basset, J. P. Candy, A. Choplin, C. Santini and A. Theolier, Catal. Today, $1989,6,1$; H. H. Lamb, B. C. Gates and H. Knözinger, Angew. Chem., Int. Ed. Engl., 1988, 27, 1127.

3 Yu. 1. Yermakov, B. N. Kuznetsov and V. A. Zakharov, Catalysis by Supported Metal Complexes, Elsevier, Amsterdam, 1981.

4 D. C. Bailey and S. H. Langer, Chem. Rev., 1981, 81, 109.

5 G. A. Ozin and C. Gil, Chem. Rev., 1989, 89, 1749.

6 G. A. Ozin and S. Ozkar, Chem. Mater., 1992, 4, 511.

7 A. Borvornwattananont, K. Moller and T. Bein, J. Chem. Soc., Chem. Commun., 1990, 28; A. Borvornwattananont, K. Moller and T. Bein, in Synthesis, Characterization and Novel Applications of Molecular Sieve Materials, ed. R. L. Bedard, T. Bein, M. E. Davis, J. Garces, V. A. Maroni and G. D. Stucky, Mat. Res. Soc. Symp. Proc., 1991, 233, 195; (c) A. Borvornwattananont, K. Moller and T. Bein, J. Phys. Chem., 1992, 96, 6713.

8 A. Borvornwattananont and T. Bein, J. Phys. Chem., 1992, 96, 9447.

9 H. R. H. Palil and W. A. G. Graham, Inorg. Chem., 1966, 5, 1401. 